\title{
EDITORIAL
}

\section{Psicologia Escolar e educacional: da teoria à prática escolar}

Teoria e prática em Psicologia escolar foi, de fato, o foco da discussão de 1500 congressistas que, vindos de todos os estados brasileiros, participaram do VII Congresso Nacional de Psicologia Escolar e Educacional (CONPE) na Universidade Tuiuti do Paraná, em Curitiba , de 21 a 24 de abril de 2005. Acre e Roraima foram os únicos estados que não se fizeram representar.

Pode-se observar quão importante é esse evento para a comunidade científica da Psicologia Escolar e Educacional brasileira pelas recentes produções científicas apresentadas. Foi um espaço para discussões, reflexões e propostas de ações que congregou tanto profissionais e estudantes de psicologia quanto os de outras áreas afins. É relevante explicitar que vários educadores vinculados à rede municipal, estadual e particular de ensino de Curitiba e região participaram ativamente do VII CONPE.

Cabe, aqui, um registro das atividades que, sob diferentes perspectivas, efetivaram a proposta de fazer um percurso da teoria à prática escolar na Psicologia Escolar e Educacional. Foram 11 conferências, 25 mini-cursos, 22 mesas redondas, 35 simpósios, 31 apresentações para partilhar experiências, 285 comunicações orais e 160 painéis de pesquisa. Além, destaque seja dado, dos cinco livros lançados, dos dois Fóruns de debates, da exposição da História da Psicologia Educacional Brasileira e do II Encontro de Estagiários.

A quantidade de informação aliada à indiscutível qualidade das atividades demonstrou o compromisso do Psicólogo Escolar com as atuais necessidades da educação brasileira, revelando o atual panorama da área. Participações tão comprometidas com a Psicologia escolar também têm sido constatadas pelo grande número de manuscritos encaminhados à revista, tanto provenientes das diferentes regiões brasileiras quanto da América Latina e Europa.

Isso revela que, além de contarmos com muitos profissionais investigando e atuando na área, a revista está com maior visibilidade e se consolidado como representante do registro e divulgação científica da área em realce. Espera-se que tal desempenho cresça e a informação e produção que compõem este periódico possa ser acessada pelo maior número possível de pessoas.

Visando atingir esta meta com dinamismo e buscando intercâmbio entre pares e pessoas interessadas na Psicologia Escolar e Educacional, a revista, como anunciado no último editorial, está sendo editada também eletronicamente. Ela faz parte da coleção de revistas da base de Periódicos Eletrônicos em Psicologia-PEPSIC (www.bvs-psi.org.br), recém lançada em parceria com a Biblioteca Virtual da Saúde - BVS- Psi. Assim, este número e os fascículos que o compõem estarão disponíveis on line e também impressos. Que as informações possam ser muito úteis a pesquisadores e profissionaise estudantes. 